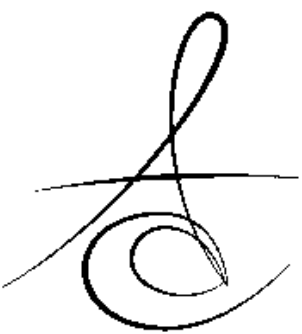

\title{
FARKLI SAGİTTAL İSKELETSEL İLİŞKİYE SAHİP PEDİATRİK ORTODONTİK BİREYLERDE FRONTAL SİNÜS BOYUTLARININ İNCELENMESİ ${ }^{*}$
}
EVALUATION OF FRONTAL SINUS DIMENSION IN DIFFERENT SAGITTAL SKELETAL RELATIONSHIP OF PEDIATRIC ORTHODONTIC SUBJECTS ${ }^{\neq}$

\author{
Dr. Öğr. Üyesi S. Kutalmış BÜYÜK* \\ Arş. Gör. Ahmet KARAMAN* \\ Dr. Öğr. Üyesi Hüseyin ŞİMŞEK ${ }^{* *}$
}

Makale Kodu/Article code: 3089

Makale Gönderilme tarihi: 28.10.2016

Kabul Tarihi: 12.01.2017

\section{öz}

Amaç: Bu çalışmanın amacı; farklı sagittal iskeletsel ilişkiye sahip bireylerde, frontal sinüs morfolojisini postero-anterior sefalometrik radyograflar kullanarak araştırılmasıdır.

Gereç ve Yöntem: 75 bireyden oluşan çalışma çenelerin sagittal iskeletsel ilişkisine göre 3 gruba ayrılmıştır (Sınıf I bireyler; ortalama yaş: 15,14 $\pm 1,40$

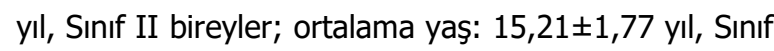
III bireyler; ortalama yaş: 15,16 $\pm 1,57$ yıl). Frontal sinüsün sağ ve sol maksimum yüksekliği ve genişliği, maksiller genişlik, nazal genişlik, kranial genişlik ve antegonial genişlik parametreleri 75 postero-anterior sefalometrik radyograf üzerinde ölçülmüştür. Veriler bağımsız $t$, Mann Whitney $U$, tek yönlü varyans analizi ve Kruskal-Wallis testleri kullanılarak analiz edilmiştir.

Bulgular: Sağ frontal sinüs yüksekliği, sol frontal sinüs yüksekliği ve genişliği gruplar arasında istatistiksel olarak anlamlı farklılık göstermiştir $(P<0.05)$. Ayrıca, Sınıf III bireylerde sağ frontal sinüs genişliği erkeklerde kadınlardan daha geniş bulunmuştur ve bu fark istatistiksel olarak anlamlıdır $(P<0.05)$.

Sonuç: Frontal sinüs boyut parametreleri farklı sagittal iskeletsel çene ilişkisine sahip bireylerde farklılık gösterebildiğinden adli diş hekimliğine farklı bir bakış açısı getirebilecektir.

Anahtar Kelimeler: Frontal sinüs, iskeletsel maloklüzyon, postero-anterior sefalometrik radyograf

\section{ABSTRACT}

Aim: The aim of this present study was to investigate frontal sinus morphology in different sagittal skeletal relationship subjects by using postero-anterior cephalometric radiographs.

Materials and Methods: The study sample consisted of 75 subjects divided into three according to their jaw sagittal skeletal relationship groups (Class I subjects; mean age: $15.14 \pm 1.40$ years, Class II subjects; mean age: 15.21 1.77 years, Class III subjects; mean age: $15.16 \pm 1.57$ years). The right and left maximum height and width of the frontal sinus, maxillary width, nasal width, cranial width, antegonial width parameters were measured in 75 posteroanterior cephalometric radiographs. The data were analyzed using independent $t$, Mann Whitney $U$, oneway analysis of variance and Kruskal-Wallis tests.

Results: Right frontal sinus height, left frontal sinus height and width show statistically significant differences among groups $(P<0.05)$. Moreover, right frontal sinus width was larger in males than females in Class III subjects and this difference was statistically $(P<0.05)$.

Conclusion: The frontal sinus dimension parameters may bring a different perspective to forensic dentistry because they may differ in individuals with different sagittal skeletal jaw relationship.

Keywords: Frontal sinus, skeletal malocclusion, postero-anterior cephalometric radiograph

\footnotetext{
* Ordu Üniversitesi Diş Hekimliği Fakültesi Ortodonti Anabilim Dalı, Ordu

** Ordu Üniversitesi Diş Hekimliği Fakültesi Pedodonti Anabilim Dalı, Ordu

* 04-07 Mayıs 2017 tarihinde Yunanistan'da gerçekleştirilen, 22. BaSS (Balkan

Stomatological Society) kongresinde sözlü sunum olarak sunulmuştur.
} 


\section{GİRIŞ}

Paranazal sinüslerden olan frontal sinüsler, frontal kemik içinde bulunan boşluklardır. Frontal sinüslerin morfolojik yapıları, adli vakalarda kimlik tanımlamasında oldukça önem taşımaktadır. Ayrıca, karakteristik özelliklerinden dolayı frontal sinüsler, parmak izi gibi her bireyde kişiye özeldir. ${ }^{1}$

Frontal sinüsler doğumda görülmezler, 2 yaşında gelişmeye başlarlar, 5 yaşında radyografik olarak gözlemlenirler. Frontal sinüslerin puberta dönemine kadar büyümesi yavaşça devam etmektedir. ${ }^{2,3}$ Frontal sinüslerin gelişimi 20 yaşında tamamen tamamlanır. ${ }^{4}$ Bebeklerde ve çocuklarda paranazal sinüsler arasındaki farkın normal ve patolojik durumlarda belirlemek zor olabilmektedir; ayrıca paranazal sinüslerin boyutu ve patolojisi arasındaki ilişki de tam olarak ilişkilendirilememiştir. $^{5-7}$

Bireyi tanımlamada en güvenilir yöntemler arasında kişilerin parmak izleri, dişlerin karşılaştırılması ve DNA profillerinin çıkarılması gösterilmektedir. ${ }^{8}$ İnsanların yanma ya da çürümeleri sonucunda arta kalan yumuşak doku kalıntıları DNA analizi yapılamayacak şekilde bozulduğunda, parmak izi tanımlaması ve DNA analizi gerçekleştirilememektedir; arta kalan kalıntılar sadece antropolojik yöntemlerle belirlenebilmektedir. Radyografi yöntemi insanların antropolojik yapılarının tanımlanmasında sıklıkla kullanılan bir yöntemdir. ${ }^{8-10}$ Frontal sinüsler monozigot ve dizigot ikizlerde değerlendirilmeleri sonucunda bile her zaman farklı tespit edilmiştir. ${ }^{11,12}$ Bundan dolayı, ante-mortem ve postmortem radyografilerde frontal sinüslerin değerlendirilmesi güvenilir bulunmuştur. ${ }^{13}$

Bu çalışmanın amacl, farklı iskeletsel maloklüzyona sahip genç erişkin Türk bireylerinde frontal sinüslerin morfolojik yapısının postero-anterior radyograflarla değerlendirilmesidir

\section{GEREÇ ve YÖNTEM}

Çalışmada kullanılan postero-anterior (PA) sefalometrik radyograflar, Ordu Üniversitesi Diş Hekimliği Fakültesi Ortodonti Anabilim Dalına başvurmuş bireylerden seçilmiştir. Arşivden 250 bireyin frontal sinüsleri anatomik ve fizyolojik bütünlük açısından değerlendirilmiştir. Ortodontik tedavi ya da ortognatik cerrahi hikayesi olan, travmaya uğramış ya da kafatası ameliyatı olmuş, endokrin bozuklukları ya da kalıtsal yüz asimetrisi olan bireyler çalışma dışında bırakılmıştır. PA radyografların şeçiminde ayrıca filmlerin rotasyonsuz çekilmiş olmalarına da dikkat edilmiştir. Sonuç olarak 75 birey üzerinde gerçekleştirilen çalışmamızda, PA radyograflar, sagittal iskeletsel sınıflamaya göre üç gruba ayrılmıştır. ANB açısı $0^{\circ}$ den küçük bireyler Sınıf III, $0^{\circ}-4^{\circ}$ arasında olan bireyler Sınıf I, $4^{\circ}$ den büyük olan bireyler Sınıf II birey olarak sınıflandırılmıştır (Tablo 1).

Tablo 1. Çalışmaya dâhil edilen bireylerin demografik özellikleri

\begin{tabular}{|c|c|c|c|c|}
\hline Gruplar & $\begin{array}{c}\text { Ortalama } \\
\text { Yaş (YıI) }\end{array}$ & $\begin{array}{c}\text { Bayan/ } \\
\text { Erkek }\end{array}$ & ANB $\left(^{\circ}\right)$ & SN-MP( $\left.{ }^{\circ}\right)$ \\
\hline Sınıf I & $15,14 \pm 1,40$ & $14 / 11$ & $2,45 \pm 1,10$ & $32,19 \pm 3,01$ \\
\hline Sınıf II & $15,21 \pm 1,77$ & $18 / 7$ & $5,39 \pm 1,14$ & $31,69 \pm 2,76$ \\
\hline Sınıf III & $15,16 \pm 1,57$ & $10 / 15$ & $-2,72 \pm 1,89$ & $31,07 \pm 3,57$ \\
\hline $\boldsymbol{P}$ & $0,988^{\mathrm{a}}$ & $0,074^{\mathrm{b}}$ & $0,000^{\mathrm{c}}$ & $0,449^{\mathrm{a}}$ \\
\hline
\end{tabular}

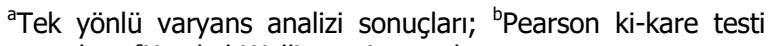
sonuçları; ' Kruskal-Wallis testi sonuçları

Bütün radyografilerde frontal sinüslerin sınırları belirlenmiştir. Orbitanın üst sınırı frontal sinüsün alt sınırı olarak alınmıştır. Frontal sinüsün alt çizgisinin yukarısında kalan bölgede sağ yükseklik, sağ genişlik, sol yükseklik ve sol genişlik parametreleri ölçüm olarak alınmıştır. Frontal sinüslerin sağ ve sol taraf olarak bölünmesi frontal sinüs septumuna dayanmaktadır. Frontal sinüsün sağ ve sol tarafındaki en alt ve en üst noktalar arasındaki mesafe, frontal sinüsün yüksekliklerini vermektedir. Frontal sinüsün sağ ve sol taraflarındaki en medial ve en lateral noktaları arasındaki mesafe ise genişlik farkını vermektedir (Şekil 1).

Çalışmamızda kullandığımız diğer iskeletsel genişlik parametreleri ise kranial genişlik (EurR-EurL), maksiller genişlik (MxR-MxL), nazal genişlik ( $L n R-L n L)$ ve antegonial genişliktir (AgR-AgL) (Şekil 2).

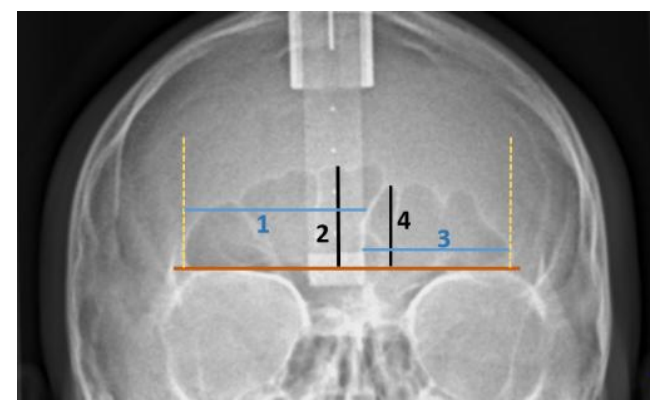

Şekil 1. Frontal sinüs ölçümleri; (1) Sağ frontal sinüs genişliği, (2) Sağ frontal sinüs yüksekliği, (3) Sol frontal sinüs genişliği, (4) Sol frontal sinüs yüksekliği. 


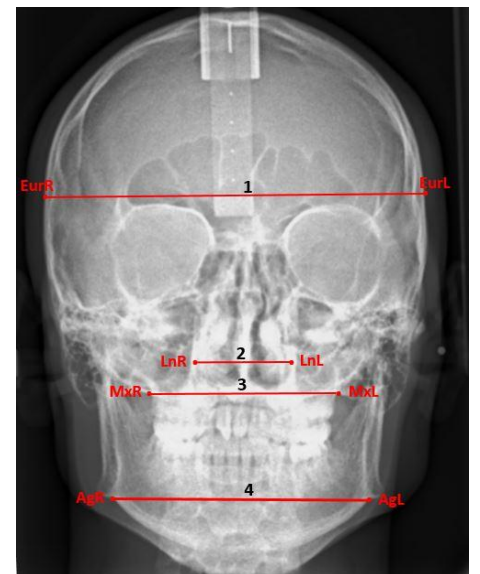

Şekil 2. Antropometrik kranial iskeletsel transversal ölçümler; (1) Kranial genişlik, (2) Nazal genişlik, (3) Maksiller genişlik, (4) Antegonial genişlik.

PA sefalogram alınırken hastanın başı düz, burun ucu radyografik kaset ile temasta ve Frankfort düzlemi yer düzlemine paralel olarak ayarlanmıştır ve tüm filmler aynı sefalometrik film cihazı (Kodak $8000 \mathrm{C}$ Digital Panoramic and Cephalometric System, Cephalostat, Corestream Health Inc, 150 Verona Street, Rochester NY, France) ile alınmıştır. Frontal sinüsün lineer ölçümleri ve diğer iskeletsel ölçümler sefalometrik yazılım programı (Facad, trial version, Linkoping, Sweden) kullanılarak gerçekleştirilmiştir.

\section{Istatistiksel Analiz}

Tüm ölçümler SPSS (SPSS for Windows version 20.0; SPSS Inc, Chicago, IL) programı kullanılarak istatiksel olarak analiz edilmiştir. Normal dağılım testi uygulandıktan sonra, normal dağılım gösteren parametrelere parametrik testler uygulanırken, normal dağılım göstermeyen testlere non-parametrik testler uygulanmıştır. Gruplar arası ölçülen verilerin analizinde tek yönlü varyans analizi ve Kruskal-Wallis testlerinden, cinsiyetler arası karşılaştırmada ise bağımsı $t$ testi ve Mann Whitney $U$ testlerinden yararlanılmıştır. Bütün testlerde, $P$ değeri $0,05^{\prime}$ den küçük olan değerler istatiksel açıdan anlamlı olarak değerlendirilmiştir.

\section{BULGULAR}

Çalışmamız Sınıf I, Sınıf II ve Sınıf III olmak üzere 3 grupta ve her grupta $25^{\prime}$ şer hasta olacak şekilde toplam 75 bireyin PA sefalometrik radyografı üzerinde gerçekleştirilmiştir. Gruplara ait demografik özellikler Tablo 1'de gösterilmiştir.
Çalışmamızda, sağ frontal sinüs yüksekliği gruplar arasında istatistiksel olarak farklılık göstermektedir $(P<0,05)$. Sağ frontal sinüs yüksekliği Sınıf I hastalarda Sınıf II ve Sınıf III hastalara göre daha yüksek bulunmuştur (Tablo 2).

Sınıf I, Sınıf II ve Sınıf III hastalar arasında sol frontal sinüs yüksekliği bakımından istatiksel olarak anlamlı fark bulunmuştur $(P<0,05)$. Sol frontal sinüs yüksekliği Sınıf I hastalarda Sınıf II ve Sınıf III hastalara göre daha yüksek bulunmuştur (Tablo 2).

Sol frontal sinüs genişliği açısından Sınıf I, Sınıf II ve Sınıf III arasında istatiksel açıdan anlamlı fark bulunmuştur $(P<0,05)$. Sol frontal sinüs genişliği, Sınıf I hastalarda Sınıf II ve Sınıf III hastalara göre daha geniş bulunmuştur (Tablo 2).

Nazal, kranial, maksiller ve antegonial genişlik bakımından gruplar arasında istatiksel olarak anlamlı fark bulunmamıştır ( $P>0,05)$ (Tablo 2$)$.

Tablo 2. Gruplar arasında frontal sinus ve kraniofasiyel parametrelerin karşılaştırılması (mm).

\begin{tabular}{|c|c|c|c|c|c|c|c|}
\hline & \multirow{2}{*}{$\begin{array}{c}\text { SINIF I } \\
\text { (Ort } \pm \text { S.S.) }\end{array}$} & \multirow{2}{*}{$\begin{array}{l}\text { SINIF II } \\
\text { (Ort } \pm \text { S.S.) }\end{array}$} & \multirow{2}{*}{$\begin{array}{l}\text { SINIF III } \\
\text { (Ort } \pm \text { S.S.) }\end{array}$} & & \multicolumn{3}{|c|}{ POST HOC TEST } \\
\hline & & & & & I-II & I-III & II-III \\
\hline $\begin{array}{l}\text { Sağ Frontal } \\
\text { Sinüs } \\
\text { Yüksekliğia }\end{array}$ & $19,28 \pm 6,24$ & $16,05 \pm 5,13$ & $14,69 \pm 5,15$ & 0,014 & 0,042 & 0,004 & 0,387 \\
\hline $\begin{array}{l}\text { Sağ Frontal } \\
\text { Sinüs } \\
\text { Genişliği }^{\text {a }}\end{array}$ & $30,70 \pm 6,83$ & 27,54 & $27,31 \pm 6,09$ & 0,106 & 0,077 & 0,058 & 0,896 \\
\hline $\begin{array}{l}\text { Sol Frontal } \\
\text { Sinüs } \\
\text { Yüksekliğgi } \\
\end{array}$ & $20,40 \pm 6,78$ & $16,60 \pm 6,77$ & $15,97 \pm 6,94$ & 0,023 & 0,027 & 0,012 & 0,900 \\
\hline $\begin{array}{l}\text { Sol Frontal } \\
\text { Sinüs } \\
\text { Genişliğia }^{\text {and }}\end{array}$ & $32,25 \pm 8,65$ & $27,12 \pm 6,43$ & $27,31 \pm 7,04$ & 0,026 & 0,017 & 0,021 & 0,929 \\
\hline $\begin{array}{c}\text { Nazal } \\
\text { Genişlik }^{\mathrm{a}}\end{array}$ & $32,79 \pm 2,57$ & $31,91 \pm 2,82$ & $31,73 \pm 3,05$ & 0,372 & 0,276 & 0,190 & 0,822 \\
\hline $\begin{array}{l}\text { Maksiller } \\
\text { Genişlik }^{\mathrm{b}}\end{array}$ & $64,08 \pm 4,01$ & $65,75 \pm 4,77$ & $62,80 \pm 3,19$ & 0,088 & 0,214 & 0,332 & 0,029 \\
\hline $\begin{array}{c}\text { Antegonial } \\
\text { Genişlik }^{\mathrm{a}}\end{array}$ & $84,70 \pm 4,12$ & $84,55 \pm 6,13$ & $84,46 \pm 4,04$ & 0,985 & 0,915 & 0,864 & 0,949 \\
\hline $\begin{array}{l}\text { Kranial } \\
\text { Genişlik }^{\mathrm{a}}\end{array}$ & $138,64 \pm 5,54$ & $139,61 \pm 6,72$ & $139,51 \pm 5,77$ & 0,823 & 0,572 & 0,612 & 0,953 \\
\hline
\end{tabular}

${ }^{\mathrm{a}}$ Tek yönlü varyans analizi sonuçları; ${ }^{\mathrm{b}}$ Kruskal-Wallis testi sonuçları; Ort: Ortalama; S.S.: Standart Sapma

Sınıf I grupta sağ frontal sinüs yüksekliği, sağ ve sol frontal sinüs genişliği erkek hastalarda, sol frontal sinüs yüksekliği ise bayan hastalarda daha yüksek bulunmuştur. Sınıf I erkek ve bayan hastalar arasında frontal sinüs parametreleri açısından istatiksel olarak anlamlı fark bulunmamıştır ( $P>0.05$ ) (Tablo 3).

Sınıf II grupta sağ frontal sinüs yüksekliği, sağ ve sol frontal sinüs genişliği erkek hastalarda, sol frontal sinüs yüksekliği ise bayan hastalarda daha yüksek bulunmuştur. Sınıf II erkek ve bayan hastalar

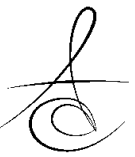


arasında frontal sinüs parametreleri açısından istatiksel olarak anlamlı fark bulunmamıştır ( $P>0,05)$ (Tablo 3)

Sınıf III grupta sağ frontal sinüs yüksekliği, sağ frontal sinüs genişliği, sol frontal sinüs yüksekliği ve sol frontal sinüs genişliği erkek hastalarda daha yüksek bulunmuştur. Sınıf III grupta erkek ve bayan hastalar arasında sağ frontal sinüs genişliği bakımından istatiksel olarak anlamlı fark bulunmuştur $(P<0,05)$ (Tablo 3).

Tablo 3. Farklı maloküzyonlarda cinsiyetler arasında frontal sinüs parametrelerinin karşılaştııı Iması $(\mathrm{mm})$.

\begin{tabular}{|c|c|c|c|c|c|c|}
\hline Gruplar & Parametreler & $\begin{array}{c}\text { Cinsiy } \\
\text { et }\end{array}$ & Sayı & Ortalama & S.S. & $\mathbf{P}$ \\
\hline \multirow{8}{*}{ 志 } & \multirow{2}{*}{$\begin{array}{c}\text { Sağ Frontal Sinüs } \\
\text { Yüksekliği }\end{array}$} & $\mathrm{KIz}$ & 14 & 8,09 & 5,58 & \multirow{2}{*}{0,293} \\
\hline & & Erkek & 11 & 20,79 & 6,69 & \\
\hline & \multirow{2}{*}{\begin{tabular}{|c|}
$\begin{array}{c}\text { Sağ Frontal Sinüs } \\
\text { Genişliği }\end{array}$ \\
\end{tabular}} & $\mathrm{KIZ}$ & 14 & 9,57 & 6,30 & \multirow{2}{*}{360} \\
\hline & & Erkek & 11 & 32,15 & 7,50 & \\
\hline & \multirow{2}{*}{\begin{tabular}{|c|}
$\begin{array}{c}\text { Sol Frontal Sinüs } \\
\text { Yüksekliği }\end{array}$ \\
\end{tabular}} & $\mathrm{KIz}$ & 14 & 12 & 6,91 & \multirow[b]{2}{*}{0,560} \\
\hline & & Erkek & 11 & 19,48 & 6,82 & \\
\hline & \multirow{2}{*}{$\begin{array}{c}\begin{array}{c}\text { Sol Frontal Sinüs } \\
\text { Genişliği }\end{array} \\
\end{array}$} & $\mathrm{KIZ}$ & 14 & 31,83 & 9,09 & \multirow[b]{2}{*}{0,191} \\
\hline & & Erkek & 11 & 78 & 8,45 & \\
\hline \multirow{8}{*}{$\begin{array}{l}\text { 兒 } \\
\text { 岁 } \\
\text { 出 }\end{array}$} & \multirow{2}{*}{\begin{tabular}{|c|}
$\begin{array}{c}\text { Sağ Frontal Sinüs } \\
\text { Yüksekliği }\end{array}$ \\
\end{tabular}} & $\mathrm{KIz}$ & 18 & & 5,37 & \multirow[b]{2}{*}{0,70} \\
\hline & & Erkek & 7 & 36 & 4,76 & \\
\hline & \multirow{2}{*}{$\begin{array}{c}\begin{array}{c}\text { Sağ Frontal Sinüs } \\
\text { Genişliği }\end{array} \\
\text {. }\end{array}$} & $\mathrm{KIz}$ & 18 & 2 & 5,53 & \multirow[b]{2}{*}{$0,5<5$} \\
\hline & & Erkek & 7 & 74 & 6,48 & \\
\hline & \multirow{2}{*}{$\begin{array}{c}\begin{array}{c}\text { Sol Frontal Sinüs } \\
\text { Yüksekliği }\end{array} \\
\end{array}$} & $\mathrm{KIz}$ & 18 & 1 & 6,91 & \multirow{2}{*}{0,545} \\
\hline & & Erkek & 7 & 67 & 6,80 & \\
\hline & \multirow{2}{*}{$\begin{array}{c}\text { Sol Frontal Sinüs } \\
\text { Genişliği }\end{array}$} & $\mathrm{Klz}$ & 18 & 26,50 & 6,10 & \multirow{2}{*}{0,451} \\
\hline & & Erkek & 7 & 71 & 7,48 & \\
\hline \multirow{8}{*}{$\begin{array}{l}\text { 曷 } \\
\text { 岕 } \\
\text { 点 }\end{array}$} & \multirow{2}{*}{\begin{tabular}{|c|}
$\begin{array}{c}\text { Sağ Frontal Sinüs } \\
\text { Yüksekliği }\end{array}$ \\
\end{tabular}} & KIz & 10 & 13,96 & 4,63 & \multirow[b]{2}{*}{0,} \\
\hline & & Erkek & 15 & 15,17 & 5,58 & \\
\hline & \multirow{2}{*}{$\begin{array}{c}\text { Sağ Frontal Sinüs } \\
\text { Genişliği }\end{array}$} & $\mathrm{KIz}$ & 10 & 24,05 & 4,42 & \multirow{2}{*}{0,025} \\
\hline & & Erkek & 15 & 29,49 & 6,20 & \\
\hline & \multirow{2}{*}{$\begin{array}{c}\text { Sol Frontal Sinüs } \\
\text { Yüksekliği }\end{array}$} & $\mathrm{K} / \mathrm{Z}$ & 10 & 14,23 & 6,29 & \multirow{2}{*}{0,317} \\
\hline & & Erkek & 15 & 17,13 & 7,31 & \\
\hline & \multirow{2}{*}{$\begin{array}{c}\text { Sol Frontal Sinüs } \\
\text { Genişliği }\end{array}$} & $\mathrm{KIz}$ & 10 & 24,64 & 6,89 & \multirow{2}{*}{0,124} \\
\hline & & Erkek & 15 & 29,09 & 6,77 & \\
\hline
\end{tabular}

${ }^{a}$ Bağımsız $\mathrm{t}$ testi sonuçları, ${ }^{\mathrm{b}}$ Mann Whitney U testi sonuçları, S.S.: Standart Sapma

\section{TARTIŞMA}

1987 yılında, Yoshino ve ark. ${ }^{13}$ frontal sinüsleri; alan boyutu, bilateral asimetri, alan boyutunun büyüklüğü, üst sınırları, parsiyal septa ve supraorbital hücreler gibi morfolojik özelliklerine dayanarak sınıflandırma sistemini önermişlerdir. Bu sistem, her morfolojik figür için bir tane numara vermektedir ve frontal sinüs paternleri formüle edilerek kod numarası her sınıflama çeşidine göre sınıflandırılarak seri numaraları ayarlanmaktadır. Bunun sonucunda frontal sinüslerin morfolojik özelliklerini tayin etmede popülasyonda bağımsız değişkenler ile düşünüldüğünde 23,040 birey içinde 1 olasılığında iki farklı birey arasında aynı belirleyici kod numarası bulunmaktadır. Adli vakaların kişisel tanımlamasında radyografiler üzerinde frontal sinüslerin değerlendirilmesi önemli rol oynamaktadır. ${ }^{14}$ Bazı yazarlar frontal sinüslerin ayırıcı tanısında bilgisayarlı tomografi kullanımını önermişlerdir. ${ }^{15}$ Paranazal sinüs patolojisinde iki boyutlu radyografi yerine bilgisayarlı tomografi kullanılması 1990'ı yılların başından beri tavsiye edilmektedir. ${ }^{16}$ Paranazal sinüslerin farklı anatomik boyutları bilgisayarlı tomografi ile görüntülenebilmektedir. Paranazal sinüslerin hacim miktarı için 3 Boyutlu tarama yapılabildiği bildirilmiştir; ayrıca farklı birçok çalışma bu tekniğin devam etmesini ve geliştirmesini sağlamaktadır. ${ }^{17-19}$ Ancak, radyasyon miktarının fazla olması nedeniyle bilgisayarlı tomografi sıklıkla tercih edilmemektedir. Bizim çalışmamız retrospektif bir çalışma olup arşivden elde edilen PA radyografları üzerinde ölçümler gerçekleştirilmiştir.

Rubier-Bullein ve ark. ${ }^{20}$ frontal sinüs pnömatizasyonunun büyük bir değişkenlik gösterdiğini belirtmişlerdir. Harris ve ark. ${ }^{21}$ ve Nambiar ve ark. ${ }^{22}$ bu değişkenliği literatürde ayrıca tanımlamış ve adli kimliklendirmede frontal sinüslerin parmak izi gibi yararlı bir yöntem olduğunu savunmuşlardır. Buckland-Wright ${ }^{23}$, Yoshino ve ark. ${ }^{13}$, Harris ve ark. ${ }^{21}$ Camargo ve ark. ${ }^{24}$ frontal sinüsü erkeklerde kadınlara göre daha geniş bulmuşlardır. Farias ve ark. ${ }^{25}$ yapmış olduğu çalışmada frontal sinüs yüksekliğini cinsiyetler arasında istatiksel olarak anlamlı bulmuştur. Çalışmamızda ise Sınıf III grupta erkek ve kadın hastalar arasında sağ frontal sinüs genişliği bakımından istatiksel olarak anlamlı fark bulunmuştur.

Camargo ve ark. ${ }^{24}$ yapmış oldukları çalışmada sağ frontal sinüs yüksekliğini erkeklerde kadınlara göre daha yüksek bulmuşlardır. Soman ve $a r k .{ }^{26}$ ise sağ frontal sinüs yüksekliğini kadınlarda daha yüksek bulmuşlardır. Bizim çalışmamızda da Camargo ve ark. ${ }^{24}$ nın bulguları ile uyumlu olarak Sınıf I, Sınıf II ve Sınıf III çalışma gruplarında erkek bireylerde daha yüksek bulunmuştur. Aradaki farklılığın Camargo ve ark. ${ }^{24}$ filmleri alırken Caldwell tekniği kullanmışken; Samon ve ark. $^{26}$ ve bizim çalışmamızda standart PA sefalometrik yöntemi kullanılmasından kaynaklanabileceği düşünül- mektedir.

Camargo ve ark. ${ }^{24}$ ve Soman ve ark. ${ }^{26}$ çalışmalarında sol frontal sinüs yüksekliğini erkeklerde kadınlara göre daha yüksek bulmuşlardır. Çalışmamızda Sınıf I ve Sınıf II gruplarda kadın hastalarda daha yük-

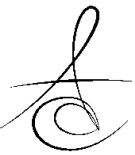


Atatürk Üniv. Diş Hek. Fak. Derg.

J Dent Fac Atatürk Uni

Cilt:28, Sayı:2, Yıl: 2018, Sayfa, 144-149

sek bulunmuşken, Sınıf III grupta erkeklerde daha yüksek bulunmuştur. Aradaki farklılık Camargo ve ark. ${ }^{24}$ nın çalışmasında bireyler iskeletsel olarak sınıflamaya tabi tutulmazken, bizim çalışma grubumuzda bireylerin sagittal yöndeki iskeletsel sınflaması dikkate alınarak frontal sinüs parametrelerinin değerlendirilmiş olması şeklinde düşünülmektedir.

Camargo ve ark. ${ }^{24}$ ve Soman ve ark. ${ }^{26}$ araştırmalarında sağ frontal sinüs genişliği erkeklerde daha geniş bulmuşlardır. Bizim çalışmamızda da Sınıf I, Sınıf II ve Sınıf III çalışma gruplarında erkek bireylerde daha geniş bulunmuştur. Sınıf III grupta erkek ve kadın hastalar arasında sağ frontal sinüs genişliği bakımından istatiksel olarak anlamlı fark bulunmuştur.

Camargo ve ark. ${ }^{24}$ ve Soman ve ark. ${ }^{26}$ çalışmalarında sol frontal sinüs genişliği erkeklerde daha geniş bulunmuştur. Bizim çalışmamızda da Sınıf I, Sınıf II ve Sınıf III maloklüzyona sahip gruplarımızdaki erkek bireylerde sol frontal sinüs daha geniş bulunmuştur. Rubira-Bulletin ve ark. ${ }^{20}$ frontal sinüslerin sol tarafda sağ taraftan daha geniş olduğunu yaptıkları çalışmalarda gösterilmişlerdir. Çalışmamızda da frontal sinüsler sol tarafda sağ taraftan daha geniş bulunmuştur.

Quatrehomme ve ark. ${ }^{11}$ kraniumdaki morfolojik farklılık cinsiyetler arasında genetik faktörlerin, beslenme, hormonal ya da kas faktörlerinden daha belirleyici olduğunu belirtmişlerdir. Bu faktörlerden dolayı Sınıf I, Sınıf II ve Sınıf III çalışma gruplarımızda frontal sinüs, erkek bireylerde ortalama olarak kadınlardan daha geniş bulunmuştur. Frontal sinüs bölgesindeki patoloji, kraniyo-fasiyal yapı, frontal kemiğin kalınlığı hatta hormonal düzeyin bile frontal sinüsü etkilediği bilinmektedir. ${ }^{27}$

Perillo ve ark. ${ }^{28}$ yaptıkları çalışmada çizim, ölçüm ve noktaların lokasyonu bakımından PA sefogramların hala transversal dento-iskeletsel değişlikleri belirlemede yüksek güvenirliğe sahip olduklarını belirtmişlerdir. Rutin ortodontik kayitlardan olan PA sefalometrik radyograflar üzerinde kraniofasiyel bölgede transvers ölçümler yapılabilmektedir. ${ }^{29,} 30$ Bizim çalışmamızda da hem frontal sinüs hem de diğer kranial ölçümler güvenilirliği kanıtlanmış olan PA radyograflar üzerinde gerçekleştirilmiştir. Frontal sinüslerin 3 boyutlu olarak tanımlanmasında bilgisayarlı tomografi kullanılabilmektedir; ancak hem radyasyon dozu hem de bu cihazın her merkezde bulunamamasından dolayı pratikte uygulama açısından PA filmlerinin avantajı nedeniyle çalışmamız bu şekilde planlanmıştır.
BÜYÜK, KARAMAN, ŞİMŞEK

\section{SONUÇ}

Her bireyde morfolojik olarak farkllık göstermesi nedeniyle frontal sinüsler adli vakalarda kimlik tanımlamasında diğer metotların yetersiz kaldığı durumlarda önem taşımaktadır. Bu çalışmanın sonucunda farklı iskeletsel maloklüzyona sahip bireylerde frontal sinüslerin boyutlarının farklılık göstermesi, adli diş hekimliğine güncel bir bakış açısı getirmiştir.

Hüseyin Şimşek, ORCID ID: 0000-0002-9868-8266

Ahmet Karaman, ORCID ID: 0000-0001-5953-0071

S. Kutalmış Büyük, ORCID ID: 0000-0002-7885-9582

\section{KAYNAKLAR}

1. Kullman L, Eklund E, Grundin R. Value of the frontal sinuses in the identification of the unknown persons. J Forensic Odonstostomatol 1990;8:3-10.

2. Morgan TA, Harris MC. The use of $X$-rays as an aid to medico-legal investigation. J Forensic Med 1953;1:28-38.

3. Riddick L, Brogdon BG, Lasswell-Hoff J, Delmas B. Radiographic identification of charred human remains through use of the dorsal defect of the patella. J Forensic Sci 1983;28:263-7.

4. Silva RF, Pinto RN, Ferreira GM, Daruge Júnior E. Importance of frontal sinus radiographs for human identification. Braz J Otorhinolaryngol 2008; 74: 798.

5. Maresh MM. Paranasal sinuses from birth to late adolescence. I. Size of the paranasal sinuses as observed in routine postero-anterior roentgenograms. Am J Dis Child 1940;60:55-78.

6. Maresh MM, Washburn AH. Paranasal sinuses from birth to late adolescence. II. Clinical and roentgennographic evidence of infection. Am J Dis Child 1940;60:841-61.

7. Odita JC, Akamaguna AI, Ogisi FO, Amu OD, Ugbodaga CI. Pneumatisation of the maxillary sinus in normal and symptomatic children. Pediatr Radiol 1986;16:365-7.

8. Rothwell BR. Principles of dental identification. Dent Clin North Am 2001;45:253-70.

9. Tang JP, Hu DY, Jiang FH, Yu XJ. Assessing forensic applications of the frontal sinus in a Chinese Han population. Forensic Sci Int 2009;183:104-3.

10. Wood RE. Forensic aspects of maxillofacial radiology: Review. Forensic Sci Int 2006;159:4755. 
11. Quatrehomme G, Fronty P, Sapanet M, Grévin G, Bailet $P$, Ollier $A$. Identification by frontal sinus pattern in forensic anthropology. Forensic Sci Int 1996;83:147-53.

12. Asherson N. Identification by frontal sinus prints. A forensic medical pilot survey. London: Lewis and Co.; 1965.

13. Yoshino M, Miyasaka $S$, Sato $H$, Seta $S$. Classification system of frontal sinus patterns by radiography. Its application to identification of unknown skeletal remains. Forensic Sci Int 1987;34:289-99.

14. Kirk NJ, Wood RE, Goldstein M. Skeletal identification using the frontal sinus region: a retrospective study of 39 cases. J Forensic Sci 2002;47:318-23.

15. Reichs KJ. Quantified comparison of frontal sinus patterns by means of computer tomography. Forensic Sci Int 1993;61:141-68.

16. White PS, Robinson JM, Stewart IA, Doyle T: Computerized tomography mini-series: an alternative to standard paranasal sinus radiographs. Aust N Z J Surg 1990;60:25-9.

17. Sanchez Fernandez JM, Anta Escuredo JA, Sanchez Del Rey A, Santaolalla Montoya F: Morphometric study of the paranasal sinuses in normal and pathological conditions. Acta Otolaryngol 2000;120:273-8.

18. Emirzeoglu M, Sahin B, Bilgic S, Celebi M, Uzun A. Volumetric evaluation of the paranasal sinuses in normal subjects using computer tomography images: a stereological study. Auris Nasus Larynx 2007;34:191-5.

19. Pirner S, Tingelhoff K, Wagner I, Westphal R, Rilk M, Wahl FM, Bootz F,Eichhorn KW. CT-based manual segmentation and evaluation of paranasal sinuses. Eur Arch Otorhinolaryngol 2009;266:50718.

20. Rubira-Bullen IR, Rubira CM, Sarmento VA, Azevedo RA. Frontal sinus size on facial plain radiographs. J Morphol Sci 2010;27:77-81.

21. Harris AM, Wood RE, Nortjé CJ, Thomas CJ. The frontal sinus: Forensic fingerprint? - A pilot study. J Forensic Odontostomatol 1987;5:9-15.

22. Nambiar $P$, Naidu MD, Subramaniam K. Anatomical variability of the frontal sinuses and their application in forensic identification. Clin Anat 1999;12:16-9.
23. Buckland-Wright JC. A radiographic examination of frontal sinuses in early British populations. Man 1970;5:512-7.

24. Camargo JR, Daruge E, Prado FB, Caria PHF, Alves MC, Silva RF, Daruge Jr E. The frontal sinus morphology in radiographs of Brazilian subjects: Its forensic importance. Braz J Morphol Sci 2007;24:239-43.

25. Farias PJ, Gonzalez RE. Existing relation between the size of the frontal sinus and the growth stages of skeletal maturation. Rev Odont Mex 2007;11:12-9.

26. Soman BA, Sujatha GP, Lingappa A. Morphometric evaluation of the frontal sinus in relation to age and gender in subjects residing in Davangere, Karnataka. J Forensic Dent Sci 2016;8.

27. Uthman AT, Al-Rawi NH, Al-Naaimi AS, Tawfeeq AS, Suhail EH. Evaluation of frontal sinus and skull measurements using spiral CT scanning: An aid in unknown person identification. Forensic Sci Int 2010;197:124-7.

28. Perillo L, De Rosa A, Laselli F, d'Apuzzo F, Grassia V, Cappabianca S. Comparison between rapid and mixed maxillary expansion through an assessment of dento-skeletal effects on posteroanterior cephalometry. Prog Orthod 2014;15:46.

29. Said OT, Rossouw PE, Fishman LS, Feng C. Relationship between anterior occlusion and frontal sinus size. Angle Orthod 2017;87:752-758.

30. Tai B, Goonewardene MS, Murray K, Koong B, Islam SM. The reliability of using postero-anterior cephalometry and cone-beam CT to determine transverse dimensions in clinical practice. Aust Orthod J 2014;30:132-42.

\author{
Yazışma Adresi \\ Dr. Öğr. Üyesi Hüseyin ŞİMŞEK \\ Ordu Üniversitesi \\ Diş Hekimliği Fakültesi \\ Pedodonti Anabilim Dalı \\ Altınordu/ORDU \\ e-mail: dr.huseyinsimsek@gmail.com
}

